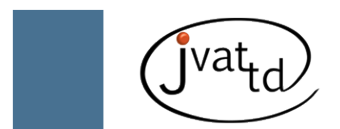

\title{
Evaluation of prognostic value of cell adhesion molecules in chronic hepatitis C therapy
}

\author{
Abdallah N (1), Morsi M (2), Hamed N (3), Abdel Aziz H (4)
}

(1) Department of Tropical Medicine, School of Medicine, University of Alexandria, Egypt; (2) Department of Microbiology and Immunology, School of Medicine, University of Alexandria, Egypt; (3) Department of Internal Medicine, Hematology Unit, School of Medicine, University of Alexandria, Egypt; (4) Department of Medical Biochemistry, School of Medicine, University of Alexandria, Egypt.

\begin{abstract}
The most reliable determination of severity and prognosis in chronic viral hepatitis is the histological staging of the disease, which comprises an invasive procedure and is often not well accepted by patients. The search for alternative non-invasive methods is mandatory especially in follow-ups after initial assessment by biopsy. The aim of this study was to evaluate the role of vascular cell adhesion molecule-1 (VCAM-1) and intercellular adhesion molecule-1 (ICAM-1) in patients under interferon alpha therapy whether responsive or non-responsive to therapy. Thirty chronic hepatitis $\mathrm{C}$ patients $(\mathrm{CHC})$ under combined therapy of interferon-a with ribavirin, whether responsive or non-responsive, were included in the study as well as ten healthy controls. Serum VCAM-1 and ICAM-1 levels were calculated using commercial enzyme linked immunosorbent assay (ELISA) kits. Before the therapy, sICAM-1 and sVCAM-1 levels were significantly higher among $\mathrm{CHC}$ patients $(96.9 \pm 39.74$ and $679.4 \pm 218.98 \mathrm{ng} / \mathrm{mL}$, respectively) than in the control group $(14.3 \pm 4.32$ and $108.9 \pm 49.21 \mathrm{ng} / \mathrm{mL}$, respectively), $(p<0.05$ for both). They were higher among non-responsive than in responsive patients. Comparisons in soluble ICAM-1 (sICAM-1) levels of responsive persons during treatment revealed a statistically significant increase at baseline (81.27 \pm $25.797)$ versus its value after one month $(52.33 \pm 12.76), p<0.05$ and after three months $(49.67 \pm 14.42), p<$ 0.05 . However, no statistically significant difference was detected between one and three-month sICAM- 1 levels post-therapy commencement $(p=0.055)$. Also, no statistically significant difference was detected between sVCAM- 1 levels at baseline $(521.47 \pm 137.29)$ versus three months after therapy initiation (517.53 $\pm 130.6), p=0.854$. The occurrence of a significant decrease in sICAM-1 level as early as one month after therapy in responsive patients only allows us to conclude that sICAM-1 could be used as an early marker in $\mathrm{CHC}$ patients under interferon therapy to predict prognosis and guide the treatment, whereas sVCAM-1 does not present any difference between the studied groups.
\end{abstract}

Key words: ICAM-1, VCAM-1, interferon, ribavirin, chronic hepatitis C.

\section{INTRODUCTION}

The World Health Organization has declared hepatitis $\mathrm{C}$ a global health problem, with approximately $3 \%$ of the world's population (roughly 170 to 200 million people) infected with HCV. In the US, approximately 3 million people are chronically infected, many of whom are still undiagnosed. In Egypt the situation is much worse (1).

Egypt has the highest prevalence of hepatitis
$\mathrm{C}$ in the world. The national prevalence rate of $\mathrm{HCV}$ antibody positivity was estimated to be 10 to $13 \%$. Since 30 to $40 \%$ of individuals clear the infection, the estimated adjusted national prevalence rate is $7.8 \%$ or 5.3 million people in 2004. Interestingly, genotype 4 represents over 90\% of cases in Egypt (1).

Chronic HCV is the main cause of liver cirrhosis and liver cancer in Egypt, and indeed, one of the top five leading causes of death (1). As expected, the availability and 
cost of treatment for hepatitis C in Egypt is quite prohibitive. Although the most common methods of preventing hepatitis $\mathrm{C}$ transmission (injection-based treatment for schistosomiasis and blood transfusions) have been addressed, the prevalence in those under age 20 is still approximately 5 to $8 \%$, demonstrating the continued presence of significant hepatitis C transmission in modern-day Egypt (1). It may be explained partly by intrafamilial viral transmission and genetic predisposition to infection (2).

Viral levels as measured by HCV RNA do not correlate with hepatitis severity or with a poor prognosis but viral load does correlate with the likelihood of a response to antiviral therapy. Response rates to a course of peginterferon and ribavirin are higher in patients with low HCV RNA levels. There are several definitions of what constitutes a «low level» of HCV RNA, but the usual definition is below 1 million IU ( 2 million copies) per milliliter. In addition, monitoring HCV RNA levels during the early phases of treatment may provide early information on the likelihood of response. Yet because of the shortcomings of the current assays for HCV RNA level, these tests are not always reliable guides to therapy (3).

Many attempts have been made to identify patients who would respond rapidly to treatment and who might be able to stop peginterferon and ribavirin early and be spared the further expense and side effects of prolonged therapy (4).

Intercellular and vascular cell adhesion molecules-1 (ICAM-1 and VCAM-1), are single-chain membrane-bound glycoproteins belonging to the immunoglobulin supergene family. In chronic hepatitis C, sICAM-1 and VCAM-1 are expressed de novo on hepatocytes infected by hepatitis $C$ virus and on endothelial cells from sinusoidal vessels, respectively. Their soluble forms reflect their level of expression in tissue (5).

The present work aimed to determine whether changes in serum levels of the cell adhesion molecules (intracellular adhesion molecule-1 and vascular cell adhesion molecule-1) as markers of inflammation and fibrosis could be monitored in hepatitis C patients during antiviral treatment to predict early response to therapy.

\section{MATERIALS AND METHODS}

This study was carried out on 30 chronic hepatitis $\mathrm{C}(\mathrm{CHC})$ patients who were on interferon (PegIFN- $\alpha 2 \mathrm{a}$ ) combined with ribavirin therapy and followed up for three months.

Since genotype 4 is most common in Africa and the Middle East, combination therapy was administered for 48 weeks. Quantitative HCV RNA was determined before the initiation of therapy at week 12 . Treatment can be discontinued in those who do not achieve an early virologic response (i.e., at least a 2-log decline from baseline of the HCV RNA level) at week 12.

Cases were selected according to:

- Clinical criteria of hepatitis and ultrasound.

- Serological evidence of elevated liver function tests, especially ALT.

- Polymerase chain reaction (PCR) for HCV in serum.

Ten normal healthy subjects of matched age and sex were included in the study to serve as a control group.

The selected patients were subjected to the following:

- History taking including age, sex and circumstantial data.

- Clinical examination.

- Routine laboratory measurements: complete blood count, serum bilirubin, ALT and AST levels.

- Ultrasound on the liver.

- Biopsy for histopathology whenever possible.

- PCR for HCV level quantitation in serum (6).

- Adhesion molecule serum levels: circulating ICAM-1 and VCAM-1 levels were estimated using commercial ELISA kits (7). The kits were supplied by Diaclone Research Company (France) and purchased by ABCO Products Inc. (France). The assay was performed and the results were estimated by strictly adhering to the manufacturer's instructions.

\section{Principle of the Assay}

The kits were solid-phase sandwich enzymelinked immuno sorbant assay (ELISA). A monoclonal antibody specific for ICAM-1 or VCAM-1 had been coated onto the wells of the microtiter strips provided. Samples - which included standards of known sICAM-1 or sVCAM-1 concentrations, control specimens 
and unknowns - were pipetted into these wells. During the first incubation, the soluble ICAM or VCAM antigen and a biotinylated monoclonal antibody specific for them were simultaneously incubated. After washing, the enzyme (streptavidin-peroxidase) was added. After incubation and washing to remove the unbound enzyme, a substrate solution that had been acted upon by the bound enzyme was added to induce a colored reaction product. The color intensity of this product was directly proportional to the concentration of sICAM-1 and sVCAM-1 present in the samples. The enzyme reaction was stopped by the addition of citric acid and the absorbance was read at $450 \mathrm{~nm}$ by a Behring ELISA reader (Germany). A standard curve was obtained by plotting the absorbances versus the corresponding concentrations of defined standards.

\section{Statistical Analysis}

The SPSS package (USA), version 9 for Windows, was used for statistical analysis of the data. Comparison between the patients and control group was done using the t-test for quantitative data and $\chi^{2}$-test for qualitative data. Paired t-test was used to compare means before and after treatment; $p \leq 0.05$ was considered significant. Data are shown as mean \pm two standard deviations (SD).

\section{RESULTS}

The study was carried out on $30 \mathrm{CHC}$ patients, 15 of whom were responsive to interferon therapy combined with ribavirin and 15 non-responsive. The 20 males (66.67\%) and ten females (33.33\%) included ranged in age from 18 to 77 with a mean of $51.17 \pm 14.96$ years.

Figure 1 presents the different levels of serum sICAM-1 (in ng/mL) at baseline and at one month and three months after initiation of interferon therapy in responsive patients. At baseline, sICAM-1 level ranged between $47-120 \mathrm{ng} / \mathrm{mL}$ with a mean value of $81.27 \pm 25.797 \mathrm{ng} / \mathrm{mL}$. Its value decreased gradually and significantly until three months of therapy where serum level of ICAM-1 ranged between 32 and $80 \mathrm{ng} / \mathrm{mL}$ with a mean value of $49.67 \pm 14.42 \mathrm{ng} / \mathrm{mL}$.

Figure 2 presents the levels of serum sICAM-1 in non-responsive patients across the duration of the study. The levels changed insignificantly from a baseline mean value of $112.53 \pm 45.62 \mathrm{ng} / \mathrm{mL}$ to

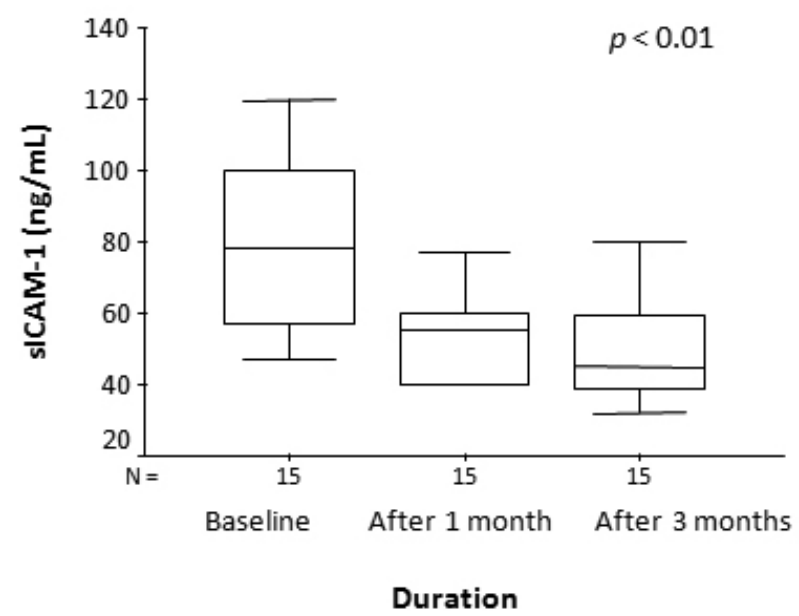

Figure 1. Comparison between SICAM values in responders at different times of the study.

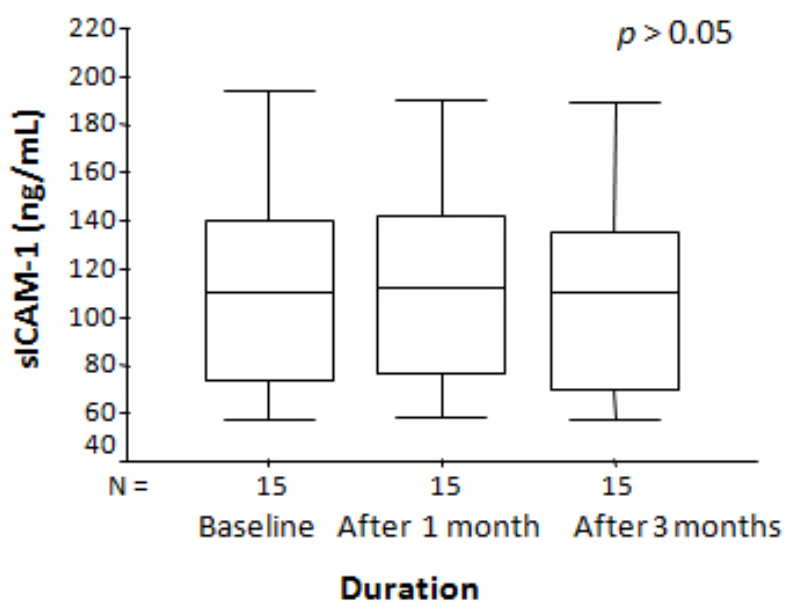

Figure 2. Comparison between sICAM values in non-responders at different times of the study.

mean value of $113.33 \pm 42.54 \mathrm{ng} / \mathrm{mL}$ three months after therapy initiation.

Table 1 shows comparison between CHC patients and the control group as to serum levels of ICAM-1 and VCAM-1. There was statistically significant increase in serum levels of sICAM-1 and VCAM-1 among patients $(96.9 \pm 39.74$ and $679.4 \pm 218.98 \mathrm{ng} / \mathrm{mL}$, respectively) in relation to the control group (14.3 \pm 4.32 and $108.9 \pm$ $49.21 \mathrm{ng} / \mathrm{mL}$, respectively), $p<0.05$ for both parameters. It was observed that the ICAM-1 and VCAM-1 values in the control group had a nonsymmetric distribution.

Table 2 demonstrates a significant difference between responsive and non-responsive patients as to mean serum sICAM-1 level at baseline and at one month and three months after therapy initiation $(p<0.05)$.

Table 3 demonstrates that VCAM-1 serum levels 
at baseline and after three months were statistically higher in non-responsive than in responsive patients ( $p<0.05$ for both).

Table 4 shows comparison between serum sICAM-1 levels in responsive patients in different treatment periods. The results revealed statistically significant increase in sICAM-1 level at baseline $(81.27 \pm 25.797)$ in comparison to its value after one month (52.33 \pm 12.76$), p<0.05$, and its value after three months (49.67 \pm 14.42$), p<0.05$. However, a statistically insignificant difference was detected between sICAM-1 level after one month and three months after initiation of therapy $(p=0.055)$ and between sVCAM-1 level at baseline (521.47 \pm 137.29) and three months after therapy initiation ( $\mathrm{p}$ $=0.854)$.

Table 5 reveals statistically insignificant difference between sICAM-1 level at baseline in comparison to its value one month $(p=0.403)$ and three months ( $p$ $=0.827$ ) after therapy initiation as well as between sVCAM-1 level at baseline and three months after therapy initiation in non-responders $(p=0.540)$.

Table 1. Comparison between serum levels of s-ICAM-1 and s-VCAM-1 in CHC group and controls at presentation

\begin{tabular}{c|c|c|c|c}
\hline \multirow{2}{*}{} & \multicolumn{2}{|c|}{ sICAM-1 $(\mathrm{ng} / \mathrm{mL})$} & \multicolumn{2}{c}{ sVCAM-1 $(\mathrm{ng} / \mathrm{mL})$} \\
\cline { 2 - 5 } & Patients $(\mathrm{n}=30)$ & Controls $(\mathrm{n}=10)$ & Patients $(\mathrm{n}=30)$ & Controls $(\mathrm{n}=10)$ \\
\hline Range & $47-194$ & $7-21$ & $300-1100$ & $67.00-190$ \\
\hline Mean \pm SD & $96.9 \pm 39.74$ & $14.3 \pm 4.32$ & $679.4 \pm 218.98$ & $108.9 \pm 49.21$ \\
\hline t-test & \multicolumn{2}{|c|}{$p<0.05$} & \multicolumn{2}{c}{$p<0.05$} \\
\hline
\end{tabular}

$p$ is significant if $\leq 0.05$

Table 2. Comparison between serum s-ICAM-1 levels $(\mathrm{ng} / \mathrm{mL})$ in responsive and non-responsive CHC patients

\begin{tabular}{c|c|c|c|c|c|c}
\hline \multirow{2}{*}{} & \multicolumn{2}{|c|}{ Base line (before treatment) } & \multicolumn{2}{c|}{ After 1 month } & \multicolumn{2}{c}{ After 3 months } \\
\cline { 2 - 7 } & $\begin{array}{c}\text { Non-responsive } \\
(\mathrm{n}=15)\end{array}$ & $\begin{array}{c}\text { Responsive } \\
(\mathrm{n}=15)\end{array}$ & $\begin{array}{c}\text { Non-responsive } \\
(\mathrm{n}=15)\end{array}$ & $\begin{array}{c}\text { Responsive } \\
(\mathrm{n}=15)\end{array}$ & $\begin{array}{c}\text { Non-responsive } \\
(\mathrm{n}=15)\end{array}$ & $\begin{array}{c}\text { Responsive } \\
(\mathrm{n}=15)\end{array}$ \\
\hline Min. & 57 & 47 & 58 & 40 & 57 & 32 \\
\hline Max. & 194 & 120 & 190 & 77 & 189 & 80 \\
\hline Mean & 112.53 & 81.27 & 113.87 & 52.33 & 113.33 & 49.67 \\
\hline SD & 45.62 & 25.797 & 43.99 & 12.759 & 42.54 & 14.42 \\
\hline t-test & \multicolumn{2}{|c|}{$p<0.05$} & \multicolumn{2}{c|}{$p<0.05$} & \multicolumn{2}{c}{$p<0.05$} \\
\hline
\end{tabular}

$p$ is significant if $\leq 0.05$.

Table 3. Comparison between serum s-VCAM-1 levels $(\mathrm{ng} / \mathrm{mL})$ in responsive and non-responsive patients

\begin{tabular}{c|c|c|c|c}
\hline \multirow{2}{*}{} & \multicolumn{2}{|c|}{ Baseline (before treatment) } & \multicolumn{2}{c}{ After 3 months } \\
\cline { 2 - 5 } & Non-responsive $(\mathrm{n}=15)$ & Responsive $(\mathrm{n}=15)$ & Non-responsive $(\mathrm{n}=15)$ & Responsive $(\mathrm{n}=15)$ \\
\hline Min. & 410 & 300 & 488 & 250 \\
\hline Max. & 1100 & 744 & 1100 & 734 \\
\hline Mean & 837.4 & 521.47 & 800.2 & 517.53 \\
\hline SD & 164.34 & 137.29 & 194.43 & 130.6 \\
\hline t-test & \multicolumn{2}{|c}{$p<0.05$} & $p<0.05$ \\
\hline
\end{tabular}

$p$ is significant if $\leq 0.05$. 
Table 4. Comparison between sICAM and SVCAM values in responsive patients at different times of the study

\begin{tabular}{c|c|c|c|c|c|c|c|c}
\hline & \multicolumn{9}{|c|}{ sICAM values (ng/mL) } & \multicolumn{2}{c}{ sVCAM values (ng/mL) } \\
\cline { 2 - 9 } & $\begin{array}{c}\text { Baseline } \\
\text { (before } \\
\text { treatment) }\end{array}$ & $\begin{array}{c}\text { After 1 } \\
\text { month }\end{array}$ & $\begin{array}{c}\text { Baseline } \\
\text { (before } \\
\text { treatment) }\end{array}$ & $\begin{array}{c}\text { After 3 } \\
\text { months }\end{array}$ & $\begin{array}{c}\text { After 1 } \\
\text { month }\end{array}$ & $\begin{array}{c}\text { After 3 } \\
\text { months }\end{array}$ & $\begin{array}{c}\text { Baseline } \\
\text { (before } \\
\text { treatment) }\end{array}$ & $\begin{array}{c}\text { After 3 } \\
\text { months }\end{array}$ \\
\hline Mean & 81.27 & 52.33 & 81.27 & 49.67 & 52.33 & 49.67 & 521.4667 & 517.53 \\
\hline SD & 25.797 & 12.76 & 25.797 & 14.42 & 12.76 & 14.42 & 137.2916 & 130.6 \\
\hline $\begin{array}{c}\text { Paired } \\
\text { t-test }\end{array}$ & \multicolumn{3}{|c|}{$p<0.05$} & \multicolumn{2}{c|}{$p<0.05$} & \multicolumn{2}{c}{$p=0.055$} & $p=0.854$ \\
\hline
\end{tabular}

$p$ is significant if $\leq 0.05$.

Table 5. Comparison between sICAM and sVCAM values in non-responders at different times of the study

\begin{tabular}{c|c|c|c|c|c|c|c|c}
\hline \multicolumn{1}{|c|}{ sICAM values $(\mathrm{ng} / \mathrm{mL})$} & \multicolumn{2}{c}{ sVCAM values (ng/mL) } \\
\hline & $\begin{array}{c}\text { Baseline } \\
\text { (before } \\
\text { treatment) }\end{array}$ & $\begin{array}{c}\text { After 1 } \\
\text { month }\end{array}$ & $\begin{array}{c}\text { Baseline } \\
\text { (before } \\
\text { treatment) }\end{array}$ & $\begin{array}{c}\text { After 3 } \\
\text { months }\end{array}$ & $\begin{array}{c}\text { After 1 } \\
\text { month }\end{array}$ & $\begin{array}{c}\text { After 3 } \\
\text { months }\end{array}$ & $\begin{array}{c}\text { Baseline } \\
\text { (before } \\
\text { treatment) }\end{array}$ & $\begin{array}{c}\text { After 3 } \\
\text { months }\end{array}$ \\
\hline Mean & 112.53 & 113.87 & 112.53 & 113.33 & 113.87 & 113.33 & 837.4 & 800.2 \\
\hline SD & 45.62 & 43.99 & 45.62 & 42.54 & 43.99 & 42.54 & 164.34 & 194.43 \\
\hline $\begin{array}{c}\text { Paired } \\
\text { t-test }\end{array}$ & \multicolumn{3}{|c|}{$p=0.403$} & \multicolumn{2}{c|}{$p=0.827$} & $p=0.877$ & & $p=0.540$ \\
\hline
\end{tabular}

$p$ is significant if $\leq 0.05$.

\section{DISCUSSION}

At present, the most reliable determination of severity and prognosis in chronic viral hepatitis is the histological staging of the disease which is an invasive procedure that is often not well accepted by patients. The search for alternative non-invasive methods is mandatory especially in follow-up after initial assessment by biopsy (8).

ICAM-1 is one of the most important adhesion molecules in immune reactions. It is thought to play a fundamental role during liver inflammation. It is expressed by hepatocytes at inflammation sites and is correlated with the degree of inflammation. The expression of ICAM-1 is regulated by several cytokines such as tumor necrosis factor, $\gamma$-interferon and interleukin-1- $\alpha$ in a dose-dependent fashion. This expression favors the adhesion of $\mathrm{T}$ lymphocytes to lymphocyte function-associated antigen (LFA)-1 on hepatocytes and may trigger an immune reaction and maintain chronic inflammation (9).
Serum sICAM-1 levels were statistically significantly higher among our $\mathrm{CHC}$ patients than controls. The elevated sICAM-1 levels in acute and chronic liver disease are due to an increased shedding from the large pool of inflammatory cells in the liver. The close relationship between ALT and sICAM-1 in different studies suggested shedding of ICAM-1 from necrotic hepatocytes. The fact that immunosuppressive therapy or IFN- $\alpha$ decreases sICAM- 1 levels may support the hypothesis that ICAM-1 behaves as an acute-phase secretory protein of hepatocytes, stimulated by inflammatory mediators (10).

The present study demonstrates the presence of a significant difference in mean serum level of ICAM-1 between responsive and non-responsive patients at baseline (before treatment) and at one month and three months after initiation of interferon therapy, a difference that was higher in non-responsive than in responsive subjects in all therapy stages.

The concentration of sICAM-1 decreased significantly only in responders during the first 3 months of therapy (11). The probability of 
response to treatment was much higher in the group showing a decrease of sICAM-1 than in the patients who did not show such a decrease. A "longitudinal" evaluation of serum levels of sICAM-1 in the first period of treatment is particularly useful in the identification of patients with a significantly high probability of responding to treatment (11).

However, most studies focus on the SICAM-1 values after three months or at six-month intervals after stopping treatment, for a total two-year follow-up (12). Comparing sICAM-1 levels at different treatment periods revealed a statistically significant increase of the sICAM-1 level at baseline in relation to its level after one month or after three months. However, at one month and three months after therapy initiation, the sICAM-1 level presented a statistically insignificant difference. The obtained results suggests that measurement of sICAM-1 level as early as one month after therapy initiation may provide data comparable to those obtained after three months.

With regard to serum sVCAM-1 levels, CHC patients in our study revealed significantly higher values than the control group. The elevated serum VCAM-1 in chronic hepatitis reported by some authors could be the consequence of persistent activation of vascular endothelial cells which are able to produce connective tissue growth factor, a highly profibrogenic molecule involved in several fibrotic disorders, including those of the liver (13).

Our results show a statistically insignificant difference between baseline sVCAM-1 and its level three months after therapy initiation. Sustained response to interferon was significantly related to low non-lb type viremia and low sICAM-1, but not to sVCAM-1 (10).

Liver necroinflammation as assessed by biochemistry and histological score was more closely related to sICAM-1 than to sVCAM-1. Fibrosis, however, was clearly related to sVCAM-1 $(1071+/-291$ in patients who scored $0-2$ vs. $1870+/-458$ in patients who scored 3-4.) Severe fibrosis was never found below the sVCAM-1 cutoff threshold of $1300 \mathrm{ng} / \mathrm{mL}$ (10). Serial determination of serum VCAM1 could be useful to identify the switch from prevalence of necroinflammation to prevalence of sclerofibrotic processes, marked by an accentuated increase of values (13).

\section{CONCLUSION}

sICAM-1 serum levels rather than sVCAM-1 levels in chronic hepatitis $\mathrm{C}$ is a useful noninvasive early marker for monitoring liver disease activity and can predict the virological response to the interferon-plus-ribavirin therapy, while VCAM-1 does not differentiate between these two groups. Prospective studies with a larger sample size are necessary to verify the use the ICAM-1 as an early marker of successful therapy.

\section{COPYRIGHT}

(C) CEVAP 2010

\section{SUBMISSION STATUS}

Received: February 21, 2010.

Accepted: May 14, 2010.

Abstract published online: June 7, 2010.

Full paper published online: August 31, 2010.

\section{CONFLICTS OF INTEREST}

There is no conflict.

\section{CORRESPONDENCE TO}

HANAN KAMAL ABDEL AZIZ, 124 Taawniat Smouha, Alexandria, Egypt. Phone: 0020 127681628. Email: hanankam60@yahoo.com.

\section{REFERENCES}

1. Mohamed MK. Epidemiology of HCV in Egypt. Afro-Arab Liver J. 2004;3(2):41-52.

2. Plancoulaine S, Mohamed MK, Arafa N, Bakr I, Rekacewicz C, Trégouët DA, et al. Dissection of familial correlations in hepatitis $\mathrm{C}$ virus (HCV) seroprevalence suggests intrafamilial viral transmission and genetic predisposition to infection. Gut. 2008; 57(9):1268-74.

3. Fried MW, Shiffman ML, Reddy KR, Smith C, Marinos G, Gonçales JR FL, et al. Peginterferon alfa-2a plus ribavirin for chronic hepatitis $\mathrm{C}$ virus infection. N Engl J Med. 2002;347(1):975982.

4. Liang TJ, Rehermann B, Seeff LB, Hoofnagle JH. Pathogenesis, natural history, treatment, and prevention of hepatitis C. Ann Intern Med. 2000;132(4):296-305.

5. Dejica D, Grigorescu M, Dejica V, Radu C, Neculoiu D. Serum levels of soluble intercellular-1 and vascular cell-1 adhesion molecules in chronic hepatitis $\mathrm{C}$ and the influence of interferonalpha + ribavirin therapy. Rom J Gastroenterol. 2002;11(4):277-83. 
6. Kato N, Yokosuka O, Omato M, Hosoda K, Ohto M. Detection of hepatitis $\mathrm{C}$ virus ribonucleic acid in the serum by amplification with polymerase chain reaction. J Clin Invest. 1990;86(5):1764-7.

7. Söderquist B, Sundqvist KG, Vikerfors T. Adhesion molecules (E-selectin, intercellular adhesion molecule-1 (ICAM-1) and vascular cell adhesion molecule-1 (VCAM-1)) in sera from patients with Staphylococcus aureus bacteraemia with or without endocarditis. Clin Exp Immunol. 1999;118(3):408-11.

8. El-Gohary AM, Fawaz N A, Hassoba HM, Serwah A, Ali M. Soluble ICAM-1 in patients with chronic hepatitis $\mathrm{C}$ infection: a prognostic marker of disease activity. Egypt J Immunol. 2004;11(2):109-19.

9. Montalto G, Giannitrapania L, Soresia M, Florena A, Di Martino D, Franco V, et al. Circulating intercellular adhesion molecule-1 in chronic hepatitis $\mathrm{C}$ patients with normal or elevated aminotransferase before and after alphainterferon treatment. Intervirology. 2003; 46(1):35-42.
10. Lo Iacono O, García-Monzón C, Almasio P, García-Buey L, Craxí A, Moreno-Otero R. Soluble adhesion molecules correlate with liver inflammation and fibrosis in chronic hepatitis $\mathrm{C}$ treated with interferon-alpha. Aliment Pharmacol Ther. 1998;12(11):1091-9.

11. Capra F, De Maria E, Lunardi C, Marchiori L, Mezzelani P, Beri R, et al. Serum level of soluble intercellular adhesion molecule 1 in patients with chronic liver disease related to hepatitis $\mathrm{C}$ virus: a prognostic marker for responses to interferon treatment. J Infect Dis. 2000;181(2):425-31.

12. Gattoni A, Romano C, Cecere A, Caiazzo R, De Bellis A, Bizzarro A. Serum levels of soluble intercellular adhesion molecule 1 (sICAM-1) as a potential marker of disease activity and remission in patients with chronic hepatitis C. Panminerva Med. 1997;39(4):256-62.

13. Bruno CM, Sciacca C, Cilio D, Bertino G, Marchese AE, Politi G, et al. Circulating adhesion molecules in patients with virus-related chronic diseases of the liver. World J Gastroenterol. 2005;11(29):4566-9. 